\title{
Evaluation of Chlorpyrifos Resistance and Biochemical Mechanisms of Culex pipiens in Five Localities of Grand Tunis Area, Northeast Tunisia
}

\author{
Jaber Daaboub ${ }^{1,2}$, Ahmed Tabbabi ${ }^{1 *}$, Ali Lamari ${ }^{1}$, Raja Ben Cheikh ${ }^{1}$, Ibtissem Ben Jha ${ }^{1}$ and Hassen Ben Cheikh ${ }^{1}$
}

${ }^{1}$ Laboratory of Genetics, Faculty of Medicine of Monastir, Monastir University, 5019, Monastir, Tunisia

${ }^{2}$ Department of Hygiene and Environmental Protection, Ministry of Public Health, 1006, Bab Saadoun, Tunis, Tunisia

\begin{abstract}
Five Culex pipiens samples were collected at preimaginal stages from breeding sites in 5 localities of Grand Tunis area, Northeast Tunisia, between March 2002 and November 2005. Larvae were used for bioassays using ethanol solutions of chlorpyrifos and propoxur insecticides. All samples were resistant to chlorpyrifos $(R R>1, p<0.05)$. The highest resistance levels (>1,000-fold) were recorded in samples \# 2, 4, and 5 . Our synergist study showed that the increased detoxification by EST (and/or GST) had only a minor role in the chlorpyrifos resistance, although several overproduced esterases, known to be involved in the OPs resistance, were detected in all the resistant field samples. The mortality due to propoxur was significantly correlated with the $\mathrm{LC}_{50}$ of chlorpyrifos and indicated an insensitive AChE.
\end{abstract}

Keywords: Culex pipiens; Chlorpyrifos; Resistance; Esterases; Insensitive AChE 1; Grand Tunis area

\section{Introduction}

Overall, surveillance activities of potential mosquito vectors of disease are very limited in Tunisia in terms of both spatial and temporal coverage and effectiveness. The problem is essentially linked to the lack of human and material resources mobilized for the activity. The hygienist technicians responsible for the activities of the entomological units are involved, at the same time, in other activities and the means at their disposal are very limited.

The current mosquito surveillance system is far from being able to predict epidemics of vector-borne diseases, evidenced by the occurrence of the several outbreak of West Nile Virus in 2003, 2007, 2010, 2011 and 2012 [1-4] despite the surveillance system putted in place after the first epidemic of 1997.

The other problem relating to potential vectors of diseases, which should be mentioned, concerns the development by mosquitoes of strong resistance to insecticides. The results of the study of insecticide resistance in populations of Culex pipiens, the most frequent and abundant mosquito in Tunisia, captured in different parts of the country showed their high level of resistance to chlorpyrifos [5-8]. This strong resistance concerns mainly Grand Tunis area of northern Tunisia.

The primary mechanism of toxicity of organophosphorus pesticides, such as chlorpyrifos, is cholinesterase inhibition (ChE). Inhibition of the enzyme acetylcholinesterase (AChE) results in an accumulation of acetylcholine (ACh) at choline receptors, resulting in continuous nerve stimulation [9]. The current study was realized to study the status of tolerance of Culex pipiens to chlorpyrifos insecticide (OP) in five localities of Grand Tunis Area of Tunisia.

\section{Materials and methods}

\section{Study area}

Tunis, Ariana, Manouba and Ben Arous are the four states of Grand Tunis area, Northeast Tunisia.

\section{Mosquitoes}

Five Culex pipiens samples were collected at preimaginal stages from breeding sites in 5 localities between March 2002 and November 2005 (Table 1). Larvae were used for bioassays and pupae were reared to imago under laboratory conditions. Two to three days after their emergence, some adults from each collection were stored in liquid nitrogen for biochemical investigations. Reference strains included S-Lab, an insecticide-susceptible strain without any known resistance genes [10], and two OPs resistant strains: SA2, a resistant strain homozygous for Ester ${ }^{2}$, displaying overproduced esterases A2-B2, and SA5, a resistant strain homozygous for Ester ${ }^{5}$, displaying overproduced esterases A5-B5 [11].

\section{Bioassays}

Assays were performed as described by Raymond et al. [12], using ethanol solutions of chlorpyrifos (99.5\% [AI]), brought from laboratory Dr Ehrenstorfer, Germany, and propoxur ( 99.9\% [AI], Bayer AG, Leverkusen, Germany). The effect on chlorpyrifos resistance of 2 synergists, the DEF ( 98\% [AI], Chem Service, England), and the $\mathrm{Pb}$ ( 94\% [AI], Laboratory Dr Ehrenstorfer, Germany), was studied by exposing larvae to a standard sublethal doses of $0.08 \mathrm{mg} /$ liter for DEF, and $2.5 \mathrm{mg} /$ liter for $\mathrm{Pb}, 4 \mathrm{~h}$ before the addition of the insecticide.

\section{Over-produced esterases}

Esterases of high activity were characterized on homogenates of adult thorax and abdomen by studying esterase activity in the presence of $\alpha$-and- $\beta$-naphtyl acetate after protein separation by starch-gel electrophoresis (TME 7,4 buffer system ) as described by Pasteur et al. [13] and were identified by comparing their electrophoretic mobility to that of known over-produced esterases.

\section{Data analysis}

Larval mortality was recorded after 24-h exposures, and data were analyzed using a log-probit program of Raymond et al. [14] based on Finney. [15].

*Corresponding author: Tabbabi A, Laboratory of Genetics, Faculty of Medicine of Monastir, Monastir University, 5019, Monastir, Tunisia, Tel: 0021697085424 Fax: 73460737; E-mail: tabbabiahmed@gmail.com

Received May 25 2017; Accepted June 12, 2017; Published June 20, 2017

Citation: Daaboub J, Tabbabi A, Lamari A, Ben Cheikh R, Ben Jha I, et al. (2017) Evaluation of Chlorpyrifos Resistance and Biochemical Mechanisms of Culex pipiens in Five Localities of Grand Tunis Area, Northeast Tunisia. Hereditary Genet 6: 183. doi:10.4172/2161-1041.1000183

Copyright: @ 2017 Daaboub J, et al. This is an open-access article distributed under the terms of the Creative Commons Attribution License, which permits unrestricted use, distribution, and reproduction in any medium, provided the original author and source are credited. 
Citation: Daaboub J, Tabbabi A, Lamari A, Ben Cheikh R, Ben Jha I, et al. (2017) Evaluation of Chlorpyrifos Resistance and Biochemical Mechanisms of Culex pipiens in Five Localities of Grand Tunis Area, Northeast Tunisia. Hereditary Genet 6: 183. doi:10.4172/2161-1041.1000183

Page 2 of 3

\begin{tabular}{|c|c|c|c|c|c|c|c|c|c|c|c|c|c|}
\hline \multirow[b]{2}{*}{ Populations } & \multicolumn{3}{|c|}{ Chlorpyrifos } & \multicolumn{5}{|c|}{ Chlorpyrifos +DEF } & \multicolumn{5}{|c|}{ Chlorpyrifos +Pb } \\
\hline & $\begin{array}{l}\mathrm{LC}_{50} \text { in } \mu \mathrm{g} / \mathrm{l} \\
\text { (a) }\end{array}$ & Slope \pm SE & $\mathrm{RR}_{50}(\mathbf{a})$ & $\begin{array}{l}L_{50} \text { in } \mu g / l \\
\text { (a) }\end{array}$ & $\begin{array}{l}\text { Slope } \\
\pm \text { SE }\end{array}$ & $\mathrm{RR}_{50}(\mathrm{a})$ & $\mathrm{SR}_{50}(\mathrm{a})$ & RSR & $\begin{array}{l}L_{50} \text { in } \mu g / I \\
\text { (a) }\end{array}$ & $\begin{array}{l}\text { Slope } \\
\pm \text { SE }\end{array}$ & $\mathrm{RR}_{50}(\mathbf{a})$ & $\mathrm{SR}_{50}(\mathrm{a})$ & RSR \\
\hline Slab & $\begin{array}{c}0.56 \\
(0.53-0.58)\end{array}$ & & & $\begin{array}{c}0.17 \\
(0.14-0.20) \\
\end{array}$ & & & & 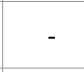 & & & - & & \\
\hline 1-Sidi thabet & $\begin{array}{c}90 \\
(49-166)\end{array}$ & & $\begin{array}{c}163 \\
(121-221)\end{array}$ & $\begin{array}{c}846 \\
(220-3230)\end{array}$ & $\begin{array}{c}0.99 \\
\pm 0.23\end{array}$ & $\begin{array}{c}5032 \\
(2769-9145)\end{array}$ & $\begin{array}{c}0.10 \\
(0.06-0.17)\end{array}$ & 0.03 & $\begin{array}{c}241 \\
(87-531)\end{array}$ & & $\begin{array}{c}481 \\
(276-838)\end{array}$ & $\begin{array}{c}0.42 \\
(0.29-0.61)\end{array}$ & 0.33 \\
\hline 2-Sokra & $\begin{array}{c}1230 \\
(665-2270)\end{array}$ & $1,71 \pm 0.39$ & $\begin{array}{c}2219(1349- \\
3652)\end{array}$ & $\begin{array}{c}1460 \\
(1120- \\
1900)\end{array}$ & & \begin{tabular}{|l|}
87 \\
$(63$ \\
118
\end{tabular} & & 0.25 & $\begin{array}{c}305 \\
(232-381)\end{array}$ & & $\begin{array}{c}684 \\
(466-1005)\end{array}$ & $\begin{array}{c}4.0 \\
(2.5-6.4)\end{array}$ & 3.2 \\
\hline 3-Mannouba & $35(19-66)$ & $0.99 \pm 0.14$ & $\begin{array}{c}64.6 \\
(45.8-91.0)\end{array}$ & $\begin{array}{c}14 \\
(5.5-37)\end{array}$ & & $\begin{array}{c}85.9 \\
(58.4-126)\end{array}$ & & 0.75 & $\begin{array}{c}21 \\
(13-35)\end{array}$ & & $\begin{array}{c}48.8 \\
(32.8-72.7)\end{array}$ & $\begin{array}{c}1.6 \\
(1.2-2.2)\end{array}$ & 1.3 \\
\hline 4-Ouardia & $\begin{array}{c}682(470- \\
1030)\end{array}$ & $0,65 \pm 0,05$ & $\begin{array}{c}1229 \\
(989-1527)\end{array}$ & $\begin{array}{c}129 \\
(95-177)\end{array}$ & & $\begin{array}{c}771 \\
(615-967)\end{array}$ & $\begin{array}{c}5.2 \\
(4.5-6.0)\end{array}$ & 1.6 & $\begin{array}{c}1860 \\
(1020- \\
4580)\end{array}$ & & & $\begin{array}{c}0.36 \\
(0.28-0.47)\end{array}$ & 0.29 \\
\hline 5-Ezzahra & $\begin{array}{c}4950(3830- \\
6850)\end{array}$ & $1.67 \pm 0.19$ & $\begin{array}{c}8929(6773- \\
11773)\end{array}$ & $\begin{array}{c}4740 \\
(3690- \\
6430)\end{array}$ & & $\begin{array}{c}28199 \\
(21728- \\
36598)\end{array}$ & $\begin{array}{c}1.04 \\
(0.80-1.3)\end{array}$ & 0.31 & $\begin{array}{c}6340 \\
(2910- \\
55400)\end{array}$ & & $\begin{array}{l}14228 \\
(8361- \\
24209)\end{array}$ & $\begin{array}{c}0.78 \\
(0.50-1.2)\end{array}$ & 0.62 \\
\hline
\end{tabular}

(a), $95 \% \mathrm{Cl}$. RR50, resistance ratio at LC50 (RR50=LC50 of the population considered/LC50 of Slab); SR50, synergism ratio (LC50 observed in absence of synergist/ LC50 observed in presence of synergist). RR and SR considered significant $(P<0.05)$ if their $95 \% \mathrm{Cl}$ did not include the value 1 . RSR, relative synergism ratio (RR for insecticide alone/RR for insecticide plus synergist).

Table 1: Chlorpyrifos resistance characteristics of Tunisian Culex pipiens in presence and absence of synergists $\mathrm{DEF}$ and $\mathrm{Pb}$.

\section{Results}

\section{Chlorpyrifos Resistance in presence and absence of synergists $\mathrm{DEF}$ and $\mathrm{Pb}$}

All samples were resistant to chlorpyrifos $(\mathrm{RR}>1, \mathrm{p}<0.05)$ (Table 1 ). The highest resistance levels ( $>1,000$-fold) were recorded in samples \# 2, 4, and 5. At $\mathrm{LC}_{95}$, the resistance levels exceeded 10,000 folds in samples \# $1,2,4$, and 5 .

The addition of DEF decreased significantly the resistance (SR50 $>1$, $\mathrm{p}<0.05$ ) of sample \# 4 where the SR was significantly higher than that recorded in S-Lab (Table 1). So, the increased detoxification by EST and/or GST was responsible, at least in part, for chlorpyrifos resistance in this sample. The addition of $\mathrm{Pb}$ to chlorpyrifos bioassays significantly decreased the resistance of samples 2 and 3 (Table 1). The recorded SR in these samples was significantly higher than that observed in S-Lab. However, oxidative metabolism accounted for only a small part of the observed resistances because chlorpyrifos resistance ratios remained significant high in the presence of the $\mathrm{Pb}$.

\section{Cross-resistance Chlorpyrifos/Propoxur}

The mortality due to propoxur varied from one sample to another. It was $0 \%$ in the most resistant strain and $21 \%$ in the most sensitive strain indicated an insensitive AChE. The mortality due to propoxur was significantly correlated with the $\mathrm{LC}_{50}$ of chlorpyrifos (Spearman rank correlation, $(\mathrm{r})=-0.90(\mathrm{P}<0.01))$.

\section{Overproduced esterases}

$\mathrm{C} 1 \mathrm{~A} 1, \mathrm{~A} 2-\mathrm{B} 2$, A4-B4 and/or A5-B5, and B12 are the five esterases detected in studied samples. It should be noted that frequency of each enzyme was not correlated with the $\mathrm{LC}_{50}$ of chlorpyrifos. For example, the sample \# 3 had $47 \%$ of A4-B4 and/or A5-B5 despite its lowest resistance to chlorpyrifos.

\section{Discussion}

The present study showed that all the studied Tunisian Culex pipiens field samples were resistant to chlorpyrifos. The resistance levels were very high in some samples $\left(\mathrm{RR}_{50}>1,000\right)$. Similar chlorpyrifos resistance levels of Culex pipiens were previously reported in Tunisia [6]. These authors showed that resistance to chlorpyrifos in populations of Culex pipiens collected from Tunisia was very important, reaching the highest level $>10,000$-folds recorded worldwide. The resistance of Culex pipiens populations collected in Grand Tunis area may be associated with the use of chlorpyrifos and other insecticides at different intensities and frequencies of application. The highest chlorpyrifos resistance level of Culex pipiens reported in other areas of the world was of 800 -fold [16]. The resistance levels to chlorpyrifos in Culex pipiens from other regions are lower: 700-fold in Israel [17], 186-fold in Italy [18], 123-fold in Martinique [19], 34-fold in Venezuela [20], 30-fold in Cote d'Ivoire [21], 14-fold in China [22] and 4-fold in Burkina Faso [23]. Other previous studies revealed that pressure using high concentrations of chlorpyrifos may induce resistance [24]. This may explain the difference in resistance to chlorpyrifos in regions under selection pressure [25].

The increased detoxification by EST and/or GST was responsible, at least in part, for chlorpyrifos resistance in just one among 5 samples despite several esterases were detected in all resistant samples. So these enzymes were not involved in recorded resistance. Our results are in agreement with previous studies on the role of the EST and the GST in the OPs resistance $[6,26]$ and the resistance levels conferred by the overproduced esterases, A2-B2, A4-B4, A5-B5 [27], C1 [6] and B12 [28]. In contrast, several previous studies showed significant elevation in the activity of esterases implicated in the resistance to OP insecticides [20,29-35]. Likewise, several studies reported the implication of GST in OPs resistance in mosquitoes including Culex and Anopheles [3640]. Our resulted mentioned the minor role of CYP450 in the recorded chlorpyrifos resistance. Similar results were reported in many insects, including mosquitoes of many countries of the world [6, 20,26, 41].

\section{Acknowledgements}

This work was kindly supported by the Ministry of Higher Education and Scientific Research of Tunisia by funds allocated to the Research Unit (Génétique 02/UR/08-03) and by DHMPE of the Minister of Public Health of Tunisia. We are very grateful to $S$. Ouanes, for technical assistance, A. Ben Haj Ayed and I. Mkada for help in bioassays, S. Saïdi, Tunisian hygienist technicians for help in mosquito collecting, and M. Nedhif and M. Rebhi for their kind interest and help.

\section{References}

1. Triki H, Murri S, Le Guenno B, Bahri O, Hili K, et al. (2001) West Nile viral meningo-encephalitis in Tunisia. Medecine Tropicale 61: 487-490.

2. Hachfi W, Bougmiza I, Bellazreg F, Bahri O, Kaabia N, et al. (2010) Second epidemic of West Nile virus meningoencephalitis in Tunisia. Med Mal Infect 40: 456-461.

3. Riabi S, Gaaloul I, Mastouri M, Hassine M, Aouni M (2014). An outbreak of WestNile virus infection in the region of Monastir Tunisia, 2003. Pathog. Global Health 108: 148-157. 
Citation: Daaboub J, Tabbabi A, Lamari A, Ben Cheikh R, Ben Jha I, et al. (2017) Evaluation of Chlorpyrifos Resistance and Biochemical Mechanisms of Culex pipiens in Five Localities of Grand Tunis Area, Northeast Tunisia. Hereditary Genet 6: 183. doi:10.4172/2161-1041.1000183

Page 3 of 3

4. Bouatef S, Hogga N, Ben Dhifallah I, Triki H, Ben Alya Bouafif N, et al. (2012) Monitoring and current situation of meningitis and meningo-encephalitis to West Nile virus in Tunisia. Tun Rev Infect 6: 181-182.

5. Ben Cheikh H, Marrakchi M, Pasteur N (1995) Mise en évidence d'une très forte résistance au chlopyrifos et à la perméthrine dans les populations de Culex pipiens en Tunisie. Archs Inst Pasteur de Tunis 72 (1/2): 7-12.

6. Ben Cheikh H, Haouas-Ben Ali Z, Marquine M, Pasteur N (1998) Resistance to organophosphorus and pyrethroid insecticides in Culex pipiens (Diptera: Culicidae) from Tunisia. J Med Entomol 35: 251-260.

7. Tabbabi A, Daaboub J, Laamari A, Ben Cheikh H (2016) New esterases amplification involved in organophosphate resistance in Culex Pipiens mosquitoes from Tunisia. The Journal of Middle East and North Africa Sciences 2(12): $1-2$

8. Tabbabi A, Laamari A, Daaboub J, Ben Jha I, Ben Cheikh H, (2017) Crossresistance to pyrethroid and organophosphorus insecticides induced by selection with temephos in the potential mosquito vector of West Nile Virus (Culex Pipiens) from Tunisia. The Journal of Middle East and North Africa Sciences 3(3): 25-29.

9. Giesy JP, Solomon KR, Coates JR, Doxon KR, Giddings JM, et al. (1999) Chlorpyrifos: Ecological risk assessment in North American environments. Reviews of Environmental Contamination and Toxicology 160: 1-130.

10. Georghiou GP, Metcalf RL, Gidden FE (1966) Carbamate resistance in mosquitoes. Selection of Culex pipiens fatigans wied for resistance to baygon. Bull Word Health Org 35: 691-708.

11. Berticat C, Boquien G, Raymond M, Chevillon C (2002) Insecticide resistance genes induce a mating competition cost in Culex pipiens mosquitoes. Genet Res 83: 189-196.

12. Raymond M, Fournier D, Bride JM, Cuany A, Bergé J, et al. (1986) Identification of resistance mechanisms in Culex pipiens (Diptera: Culicidae) from southern France: Insensitive acetylchlinesterase and detoxifying oxidases. J Econ Entomol 79: 1452-1458.

13. Pasteur N, Pasteur G, Catalan J, Bonhomme F, Britton-Davidian J (1988). Practical isozyme genetics. Ellis Horwood, Chichester, United Kingdom.

14. Raymond M, Prato G, Ratsira D (1993) PROBIT. Analysis of mortality assays displaying quantal response. Praxeme (Licence No. L93019), Saint Georges d'Orques, France.

15. Finney DJ (1971) Probit analysis. Cambridge University Press, Cambridge.

16. Mouchès C, Magnin M, Bergé JB, Desilvestri M, Beyssat V, et al. (1987) Overproduction of detoxifying esterases in organophosphate resistant Culex mosquitoes and their presence in other insects. Proc Nat Acad Sci USA 84: 2113-2116.

17. Orshan L, Kelbert M, Pener H (2005). Patterns of insecticide resistance in larval Culex pipiens populations in Israel: Dynamics and trends. J Vect Eco 30: $289-294$

18. Silvestrini F, Severeni C, Dipardo V, Romi R, Matthaeis ED, et al. (1998) Population structure and dynamics of insecticide resistance genes in Culex pipiens populations from Italy. Heredity 81: 342-348.

19. Yebakima A, Marquine M, Rosine J, Yp-tcha MM, Pasteur N (2004) Evolution of resistance under insecticide selection pressure in Culex pipiens quinquefasciatus (Diptera: Culicidae) from Martinique. J Med Entomol 41: 718-725.

20. Bisset JA, Rodriguez MM, Diaz C, Soca A (1999) Characterization of resistance to organophosphate insecticides, carbamates, and pyrethroids in Culex quinquefasciatus from the state of Miranda, Venezuela. Rev Cubana Med Trop 51: 89-94.

21. Chandre F, Darriet F, Darder M, Cuany A, Doannio JMC, et al. (1998) Pyrethroid resistance in Culex quinquefasciatus from West Africa. Med Vet Entomol 12: 359-366.

22. Cui F, Raymond M, Berthomieu A, Alout H, Weill M, et al. (2006) Recent emergence of insensitive acetylcholinesterase in Chinese populations of the mosquito Culex pipiens (Diptera: Culicidae). J Med Entomol 43: 878-883.

23. Ouedraogo TDA, Baldet T, Skovmand O, Kabre G, Guiguemde TR (2005) Sensibilité de Culex quinquefasciatus aux insecticides à Bobo Dioulasso Burkina Faso). Bull Soc Pathol Exot 98: 406-410.

24. Armes NJ, Jadhav DR, De Souza KR (1996) A survey of insecticide resistance in $H$. armigera in the Indian subcontinent. Bull Entomol Res 86: 499-514.

25. Kanga LHB, Pree DJ, Lier JLV, Walker GM (2003) Management of insecticide resistance in oriental fruit moth Grapholita molesta; (Lepidoptera: Tortricidae) populations from Ontario. Pest Manag Sci 59: 921-927.

26. Liu H, Xu Q, Zhang L, Liu N (2005) Chlorpyrifos resistance in mosquito Culex quinquefasciatus. J Med Entomol 42: 815-820.

27. Raymond M, Heckel DG, Scott JG (1989) Interactions between pesticide genes. Model and experiment. Genetics 123, 543-551.

28. Ben Cheikh R, Berticat C, Berthomieu A, Pasteur N, Ben Cheikh H, et al. (2008) Characterization of a novel high-activity esterase in Tunisian populations of the mosquito Culex pipiens. J Econ Entomol 2: 484-491.

29. Whyard S, Downe AFR, Walker VK (1994) Isolation of an esterase conferring insecticide resistance in the mosquito Culex tarsalis. Insect Biochem Mol Biol 24: 819-827.

30. Tomita T, Kono Y, Shimada T (1996) Chromosomal localization of amplified esterase genes in insecticide resistant Culex mosquitoes. Insect Biochem Mol Biol 26: 853-857.

31. Hemingway J, Karunaratne SH (1998) Mosquito carboxylesterases: A review of the molecular biology and biochemistry of a major insecticide resistance in mechanism. Med Vet Entomol 12: 1-12.

32. Hemingway J, Hawkes N, Prapanthadara L, Jayawardenal KG, Ranson H (1998) The role of gene splicing, gene amplification and regulation in mosquito insecticide resistance. Phil trans R Soc Lond B Biol Sci 353: 1695-1699.

33. Rodriguez MM, Bisset J, Fernandez DMD, Lauzan L, Soca A (2001) Detection of insecticide resistance in Aedes aegypti (Diptera: Culicidae) from Cuba and Venezuela. J Med Entomol 38: 623-628.

34. Macoris MLG, Andrighetti MTM, Takaku L, Glasser CM, Garbeloto VC, et al. (2003) Mem Inst Oswaldo Cruz Rio de Janeiro 98: 703-708.

35. Abu-El Seoud S, Abd-El Samie EM, Abdel Basset TT (2005) Toxicological and biochemical characteristics of certain insecticides on chlorpyrifos resistan strains of the pink bollworm, Pectinophora gossypiella (Saunders) in Egypt. $J$ Egypt Acad Soc Environ Dev (C-Mol. Biol.) 6: 63-89.

36. Hemingway J, Miyamoto J, Herath PRJ (1991) A possible novel link between organophosphorus and DDT insecticide resistance genes in Anopheles supporting evidence from fenitrothion metabolism studies. Pestic Biochem Physiol 39: 49-56.

37. Huang HS, Hu NT, Yao YE, Wu CY, Chiang SW, et al. (1998) Molecula cloning and heterologous expression of a glutathione-s-tranferase involved in insecticide resistance from the diamondback moth Plutella xylostella. Insect Biochem Mol Biol 28: 651-658.

38. Wei SH, Clark AG, Syvanen M (2001) Identification and cloning of a key insecticide-metabolizing glutathione -S- transferase (MdGST-6A) from a hype insecticide-resistant strain of the house fly Musca domestica. Insect Biochem Mol Biol 31: 1145-1153.

39. Hemingway J, Hawkes N, McCarroll I, Ranson H (2004) The molecular basis of insecticide resistance in mosquitoes. Insect Biochem Mol Biol 34: 653-665.

40. Zayed AB, Szumlas DE, Hanafi HA, Fryauff DJ, Mostapha AA, et al. (2006) Use of bioassay and microplate assay to detect and measure insecticide resistance in field populations of Culex pipiens from filariasis endemic areas of Egypt. $J$ Am Mosq Control Assoc 22: 473-482

41. Liu N, Yue X (2000) Insecticide resistance and cross-resistance in the house fly (Diptera: Muscidae). J Econ Entomol 93: 1269-1275. 